\title{
Identification of candidate type 3 effectors that determine host specificity associated with emerging Ralstonia pseudosolanacearum strains
}

\author{
Ana M. Bocsanczy $($ D $\cdot$ Peter Bonants $\cdot$ Jan van der Wolf • \\ Maria Bergsma-Vlami $\cdot$ David J. Norman
}

Accepted: 22 December 2021 / Published online: 6 January 2022

This is a U.S. government work and not under copyright protection in the U.S.; foreign copyright protection may apply 2021

\begin{abstract}
Ralstonia pseudosolanacearum (Rps), previously known as $R$. solanacearum phylotypes I and III is one of the causal agents of bacterial wilt, a devastating disease that affects more than 250 plant species. Emerging Rps strains were identified infecting new hosts. P824 Rps strain was isolated from blueberry in Florida. Rps strains including PD7123 were isolated from hybrid tea roses in several countries through Europe. P781 is a representative strain of Rps commonly found on mandevilla in Florida. UW757 is a strain isolated from osteospermum plants originating in Guatemala. These strains are phylogenetically closely related and of economic importance on their respective hosts. The objective of this study is to associate the Type 3 Effectors (T3Es) repertoire
\end{abstract}

Supplementary Information The online version contains supplementary material available at https://doi. org/10.1007/s10658-021-02455-w.

A. M. Bocsanczy $(\bowtie) \cdot$ D. J. Norman

Mid-Florida Research and Education Center, University of Florida Department of Plant Pathology, Apopka, FL, USA

e-mail: anamariab@ufl.edu

P. Bonants $\cdot$ J. van der Wolf

BU Biointeractions \& Plant Health, Wageningen

University \& Research, Wageningen, The Netherlands

M. Bergsma-Vlami

National Reference Center (NRC), Dutch National Plant Protection Organization (NPPO-NL), Wageningen, the Netherlands of these four strains with host specificity. Candidate T3E associated with host specificity to blueberry, tea rose, osteospermum, and mandevilla were identified by sequence homology. Pathogenicity assays on 8 hosts including, blueberry, mandevilla, osteospermum and tea rose with the 4 strains showed that both P824 and PD7123 are pathogenic to blueberry and tea rose. P781 is the only strain pathogenic to mandevilla and P824 is the only strain non-pathogenic to osteospermum. Hypotheses based on correlation of $\mathrm{T} 3 \mathrm{E}$ presence/absence and pathogenicity profiles identified 3 candidate virulence and 3 avirulence T3E for host specificity to blueberry and tea rose. Two candidate avirulence T3E were identified for mandevilla, and one candidate virulence for osteospermum. The strategy applied here can be used to reduce the number of host specificity candidate genes in closely related strains with different hosts.

Keywords Ralstonia pseudosolanacearum $\cdot$ Host specificity · Virulence · Avirulence · Type 3 effectors

\section{Introduction}

Bacterial wilt is considered one of the most devastating bacterial diseases in the world (Mansfield et al., 2012). The bacterial wilt organism until recently was classified in the Ralstonia solanacearum species complex (RSSC), which is subdivided into 4 phylotypes based on the sequence homology of the 16S-23S 
rRNA internal transcribed spacer (ITS) region (Fegan and Prior, 2005). The division in phylotypes is useful since the groups have a phylogenetic base and are correlated with geographic origin. Evidence points to phylotype I originating in Asia and Oceania, phylotype II in the Americas, phylotype III in Africa, and phylotype IV in Indonesia and Asia (Prior and Fegan, 2005; Castillo and Greenberg, 2007). Recently, using genomic and proteomic methods these phylotypes were separated into three distinct species with phylotype I and III being placed into Ralstonia pseudosolanacearum, phylotype II into Ralstonia solanacearum, and phylotype IV into Ralstonia syzygii (Safni et al., 2014; Prior et al., 2016). To study subspecies populations, strains have been distinguished on the basis of the endoglucanase (egl) gene sequences into sequevars (Fegan and Prior, 2005). Sequevar classification provides information about the genomic similarity of closely related populations of the RSSC, and it may provide clues on similar host ranges or common geographic origins (Remenant et al., 2010; Wicker et al., 2012). However, so far, no classification has been able to determine a clear relationship between genotype and host range phenotype.

Each year over 4 billion propagative plant cuttings of greenhouse ornamental plants are brought into the United States (Drotleff, 2018). It is impossible to screen all these propagative cuttings for plant diseases. The systemic nature of the bacterial wilt pathogen along with the ability to remain asymptomatic under non- conducive to disease environments, lends it to easy movement between cuttings. The authors and others have documented a number of RSSC strain introductions into the United States (Norman et al., 2009; Hong et al., 2012; Tran et al., 2016; Weibel et al., 2016).

In recent years, there have been three reports of new hosts of $R$. pseudosolanacearum phylotype I into the United States and another in Europe. The first report in the United States was noted on the ornamental mandevilla (Ruhl et al., 2011). This population was already present in greenhouses in 2007 and has now established itself in mandevilla production in South Florida (Bocsanczy et al., 2014). In 2014 phylotype I strains were found infecting imported cuttings of Osteospermum, Petunia, Calibrachoa, Verbena, and Lobelia spp. originating from Guatemala (Weibel et al., 2016). Multiple sequevars of RSSC were found on blueberry production in Florida in
2016 (Norman et al., 2017; Norman et al., 2018). The most prevalent and destructive was caused by phylotype I strains. The same year, phylotype I strains were described on tea rose in Europe (Tjou-Tam-Sin et al., 2017; Bergsma-Vlami et al., 2018). The presence of phylotype I on new hosts could be due to changes in their genotype, to adapt to new hosts, or climatic changes that expand the geographical area of the pathogen or allow the introduction of new crops in areas where RSCC is endemic. Sarkar et al. (2006) postulated that specific pathogenicity determinants distributed heterogeneously among strains are good candidates to explain host specificity (Sarkar et al., 2006). Among these are Type 3 Effectors (T3Es), proteins with diverse functions that are translocated into host cells by the Type III Secretion System (T3SS) (Sarkar et al., 2006; Guidot et al., 2007). This system is conserved among bacteria, and it can translocate up to 35 T3Es in the host cell (Chang et al., 2005; Schechter et al., 2006; Lonjon et al., 2016). T3Es functions are related to virulence and promoting disease in the host (Khan et al., 2018; Landry et al., 2020). In some cases, T3Es are recognized by the plant, resulting in an Effector Triggered Immunity response (ETI), in that instance the effector is called an avirulence factor (Jones and Dangl, 2006). Thus, depending on the specific pathogen-host interaction, a T3E can act as a virulence factor expanding the host range of the pathogen (Angot et al., 2006; Macho and Zipfel, 2015; Macho, 2016) or it can act as an avirulence factor restricting the host range (Lavie et al., 2002; Poueymiro et al., 2009; Bocsanczy et al., 2012; Nakano and Mukaihara, 2019a). RSSC has a large repertoire of T3Es. Peeters and al. 2013 identified 72 different effectors in the model strain GMI1000. They established the Ralstonia Injected Proteins (Rip) nomenclature, which we follow in this work, as well as their prediction software (https://iant.toulouse.inra. $\mathrm{fr} /$ bacteria/annotation/site/prj/T3Ev3/) (Peeters et al., 2013; Sabbagh et al., 2019).

The objective of this study was to identify candidate T3Es associated with host specificity of $R$. pseudosolanacearum closely related phylotype I strains that had been recently isolated into the US or Europe from blueberry, rose, osteospermum and mandevilla hosts. We compared genomic sequences, specifically their T3Es repertoire, in relation to their host specificity. With this information, we identified the T3Es repertoire of four closely related phylotype I strains 
recently introduced in the US and Europe and candidate T3Es associated with their host specificity. This work presents a strategy based on comparative T3Es repertoire in phylogenetically closely related strains with different host specificities to reduce the number of host specificity candidates and contributes to the identification of host specificity genetic determinants in $R$. pseudosolanacearum phylotype I. This knowledge ultimately will aid in assessing risk of epidemics and developing management strategies for this destructive pathogen.

\section{Materials and Methods}

Strains and genome sequences

Four phylogenetically closely related strains of $R$. pseudosolanacearum isolated from different hosts were selected for this work: P781, isolated from mandevilla plants, UW757 from osteospermum, P824 from blueberry and PD7123 (CFBP 8587) from tea rose. As indicated in Table 1 all four strain genomes have been sequenced and annotated previously.

\section{Similarity comparisons}

To calculate similarity between strains, whole genome sequences similarity was calculated by Average Nucleotide Identity (ANI) index using the ANI/ AAI-Matrix estimates all-vs-all distances software (http://enve-omics.ce.gatech.edu/g-matrix/ ) in a collection of $34 R$. pseudosolanacearum genomes (Rodriguez- $\mathrm{R}$ and Konstantinidis, 2016). The software calculates the distance by building a similarity clustering. The clustering method was UPGMA, tree type was phylogram unrooted. The collection of multifasta sequences of the draft genomes were used as input in a zip file for the calculation of similarity.

Comparative genomics and orthologues identification

The annotated genome sequences of strains P781, P824, UW757 and PD7123, were aligned with MAUVE (Darling et al., 2004) using the option "Align with progressive MAUVE". Since RSSC genomes (including $R$. pseudosolanacearum) are bipartite (chromosome and megaplasmid) and all the strains genomes are draft genomes, separated in scaffolds or contigs, the sequences were concatenated with Geneious Prime (Biomatters LTD.) version 202.0.4 before alignment with MAUVE. After alignment, the orthologues among strains were identified and extracted with the option "Export Orthologs" with $70 \%$ minimum similarity and $70 \%$ minimum coverage. The orthologues file was processed, and genes were grouped by their presence or absence in each strain or group of strains.

Type 3 effectors (T3Es) prediction

The repertoire of T3Es was predicted using Ralsto T3E (Peeters et al., 2013; Sabbagh et al., 2019) web software (https://iant.toulouse.inra.fr/bacteria/ annotation/site/prj/T3Ev3/). The concatenated fasta files of each strain were used as input files. The predicted T3Es protein and DNA sequences were manually curated. They were compared with the sets of

Table 1. Ralstonia pseudosolanacearum (phylotype I) strains and genomes used in this study

\begin{tabular}{|c|c|c|c|c|c|c|c|}
\hline Strain & Sequevar & Source host & Place isolation & Year isolation & $\begin{array}{l}\text { Genome Refseq } \\
\text { accession \# }\end{array}$ & Sequence status & Reference \\
\hline P781 & 14 & Mandevilla & Florida & 2014 & $\begin{array}{l}\text { NZ_ } \\
\text { JXLK00000000.1 }\end{array}$ & Contig & $\begin{array}{l}\text { (Bocsanczy et al., } \\
\text { 2017) }\end{array}$ \\
\hline UW757 & 14 & Osteospermum & Guatemala & 2014 & $\begin{array}{l}\mathrm{NZ}_{-} \\
\mathrm{LFJP} 00000000.1\end{array}$ & Scaffold & (Weibel et al., 2016) \\
\hline P824 & 12 & Blueberry & Florida & 2017 & $\begin{array}{l}\text { NZ_CP025741.1 } \\
\quad(\text { Chr }) \quad \text { NZ_- } \\
\text { CP025742).1 (MP) }\end{array}$ & Scaffold & $\begin{array}{l}\text { (Bocsanczy et al., } \\
\text { 2019) }\end{array}$ \\
\hline PD7123 & 33 & Tea Rose & Netherlands & 2015 & $\begin{array}{l}\text { JAC- } \\
\text { WOZ010000000 }\end{array}$ & Contig & $\begin{array}{l}\text { (Tjou-Tam-Sin et al., } \\
\text { 2017; Bergsma- } \\
\text { Vlami et al., 2018) }\end{array}$ \\
\hline
\end{tabular}


orthologues identified by MAUVE, and searched in the NCBI database using BLASTn, BLAStp, and tBLASTn (Altschul et al., 1990) with default parameters in order to verify presence or absence of individual genes and assign the annotation. T3E sets were compared and candidate T3E associated with host range were selected based on the hypotheses formulated. A Venn diagram was constructed to help visualize distribution of identified effectors with Venny 2.1.0 software (https://bioinfogp.cnb.csic.es/tools/ venny/ )(Oliveros, 2007-2015).

\section{Validation of T3Es candidate sequences}

PCR primers were designed (Online Resource 1) to amplify the complete gene region of the candidates with uncertain sequences or to confirm pseudogenes. PCR reactions were prepared with the TaqMan ${ }^{\mathrm{TM}}$ Universal Master Mix Cat. 4304437 following manufacturer instructions. The PCR protocol was $95{ }^{\circ} \mathrm{C} 5$ $\min , 25 \times\left[95{ }^{\circ} \mathrm{C} 15 \mathrm{~s}, \mathrm{X}\right.$ annealing ${ }^{\circ} \mathrm{C}$ for $30 \mathrm{~s}, \mathrm{Y}$ extension min], $72{ }^{\circ} \mathrm{C} 10 \mathrm{~min}$. Annealing temperatures $(\mathrm{X})$ and extension times $(\mathrm{Y})$ are indicated in Online resource 1. PCR products amplified with the same primers (Online Resource 1) were sent to Psomagen USA for Sanger sequencing. Sequences were processed and analyzed with Clone Manager 9 Professional Edition.

\section{Protein alignments}

Translated proteins either from $\mathrm{T} 3 \mathrm{E}$ predictions, tBLASTn or annotated in NCBI were aligned using the Align Multiple Sequences menu of Clone Manager 9 Professional Edition, using the multiway option (exhaustive pairwise alignments of all sequences and progressive assembly of alignment analysis of the sequences using Neighbor-Joining). Scoring matrix BLOSUM 62. Similarity for the group was taken for the minimum $\%$ of Match nucleotides.

\section{Pathogenicity tests}

Eight host plants were selected for this study: Mandevilla boliviensis 'Brides Cascade', Osteospermum sp. 'Margarita Purple 102/100 TY', southern highbush blueberry Vaccinium corymbosum 'Arcadia', hybrid tea rose Rose spp. 'Moonlight Romantica', grandiflora rose 'American Magic', miniature rose
'Mandarin Sunblaze', knock out rose 'Double Red', and tomato Solanum lycopersicum 'Walter'. Plant propagation plugs were acquired from local providers and planted into 4" pots containing a peat based potting media (Jolly Gardener Potting Mix \#2). Plants were established in a greenhouse until they were well rooted and approximately $10 \mathrm{~cm}$ in height. Pathogenicity screening was done in environmental chambers set at $28{ }^{\circ} \mathrm{C} / 20{ }^{\circ} \mathrm{C}$ on a $12 \mathrm{~h} / 12 \mathrm{~h}$ day/night cycle with a set relative humidity of $65 \%$.

For inoculum production bacterial strains were grown on Bacto Nutrient Agar amended with 5\% sucrose at $28{ }^{\circ} \mathrm{C}$ for $48 \mathrm{~h}$. Bacterial strains were harvested from culture plates, suspended in sterile saline solution $(8.5 \mathrm{~g} / \mathrm{L} \mathrm{NaCl})$ and spectrophotometrically $(600 \mathrm{~nm})$ adjusted to $1 \times 10^{8} \mathrm{cfu} / \mathrm{ml}$. Each plant was wounded at the base with a sterile scalpel approximately $1 \mathrm{~cm}$ above the soil line. Individual strains were inoculated into the wound by pipetting $10 \mu \mathrm{l}$ of the inoculum suspension (for a total \# of $1 \times 10^{6} \mathrm{cfu}$ ). Negative control plants were inoculated in the same manner with sterile saline solution. Plants were kept in an environmental chamber for 45 days and monitored for symptom development. Ten plants were used per treatment and experiment was replicated three times. To verify the presence of systemic bacterial infections, a $1 \mathrm{~cm}$ stem sample located approx. 7 $\mathrm{cm}$ above the site of inoculation was cut from each stem either at the end of the experiment (asymptomatic plants), or when the plant was completely wilted (symptomatic plants). Samples were surface disinfested for $3 \mathrm{~min}$ in a $10 \%$ Clorox solution, rinsed in sterile distilled water, ground in $300 \mu$ of sterile distilled water, dilution streaked onto triphenyl tetrazolium chloride medium (TTC) (Kelman, 1954) and plates were incubated at $28{ }^{\circ} \mathrm{C}$ for $48 \mathrm{~h}$. Presence or absence of typical $R$. pseudosolanacearum growth was then recorded.

\section{Results}

Genomes of phylotype I strains are highly conserved

The whole genome ANI index was calculated for 34 P. pseudosolanacearum strains selected from the NCBI database of Ralstonia genomes spanning the range of know sequevars. Clearly phylotype III strains cluster separately from phylotype I. Although 
the UPGMA ANI similarity tree does not cluster the four strains together (Fig. 1A), the phylotype I group shown is conserved since the lowest similarity of the 28 phylotype I strains showed in the tree is $98.84 \%$ between RS_10_244 and PD3278 and the average similarity is $99.21 \%$ (Fig. 1B). The highest similarity for the four strains analyzed in this work is between strain PD7123 (tea rose) and Rs-09-161 (99.99\%) isolated from eggplant in India (Ramesh et al., 2014), and the lowest between PD7123 and P781 (99.03\%). Similarities between UW757 and P781 (99.23\%) were close to the average for the phylotype I group (99.21\%), while similarities between P824 and P781 (99.17\%); P824 and UW757 (99.15\%); PD7123 and
P824 (99.09\%); and PD7123 and UW757 (99.05\%) were below average (Fig 1B). It is important to highlight that in this ANI comparison the differences are small and the resolution of the branch placement in the similarity tree is low for Phylotype I strains.

Genomic comparison

Genome comparison of strains P781, P824, UW757 and PD7123 confirmed their phylogenetic relatedness. The pangenome contained 6833 genes with 3980 in the core genome (58.25\%) (Fig.4). This is a high number compared with the average 2400 to 2800 core genes per $R$. solanacearum species complex
Fig. 1 Genome similarity for $34 R$. pseudosolanacearum strains. The whole draft or complete genomes were aligned using the ANI method. a) UPGMA unrooted tree of similarities b) selected pairwise comparisons

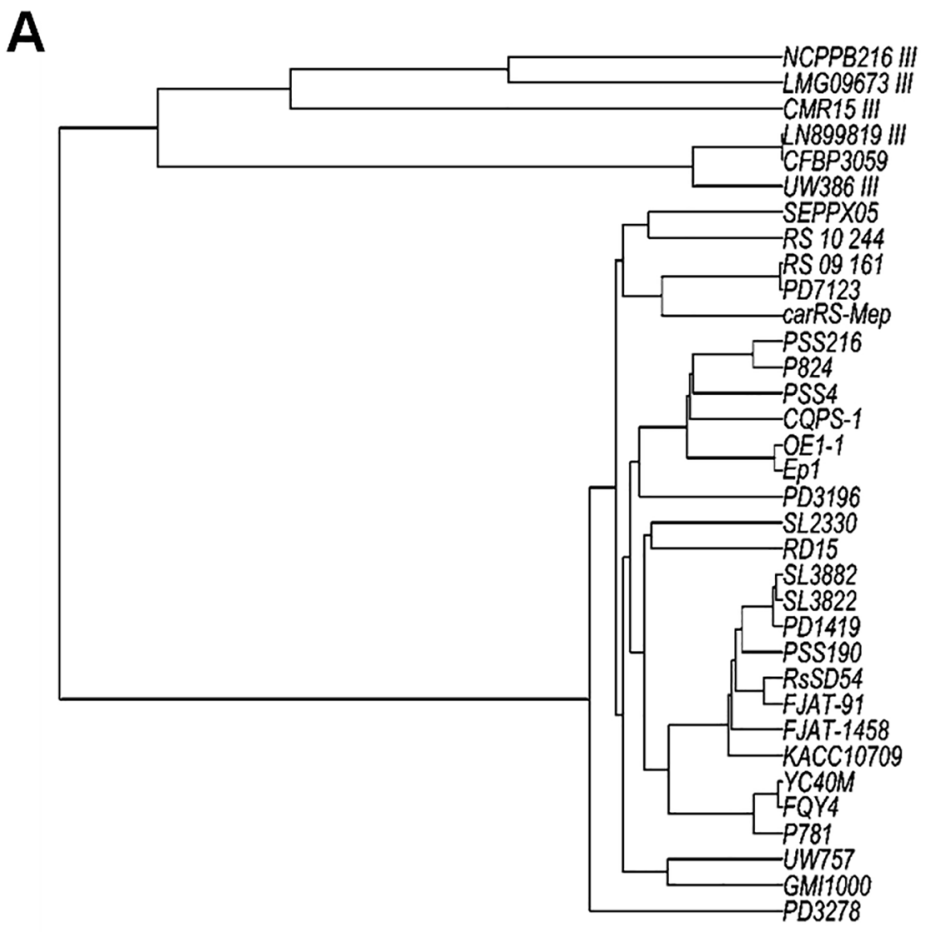

B Selected Pairwise ANI \% for Phylotype I:

$\begin{array}{lrlr}\text { PD7123 to Rs-09-161 99.99 } & \text { P824 to UW757 } & 99.15 \\ \text { P781 to FQY4 } & 99.84 & \text { PD7123 to P824 } & 99.09 \\ \text { P824 to PSS216 } & 99.84 & \text { PD7123 to UW757 } & 99.05 \\ \text { UW757 to P781 } & 99.23 & \text { PD7123 to P781 } & 99.03 \\ \text { P824 to P781 } & 99.17 & \text { RS_10_244 to PD3278 } & 98.84\end{array}$

Average phylotype I

Average R. pseudosolanacearum $\quad \mathbf{9 8 . 2 1}$ 
genomes (Remenant et al., 2010; Remenant et al., 2011; Bocsanczy et al., 2017). The number of unique genes present in individual strains ranged from 465 (6.8\%) for UW757 to 726 (10.6\%) for PD7123. The higher number of unique genes in PD7123 is consistent with its higher genomic distance from the other strains.

\section{Host Specificity}

The hosts selected for this study included the original hosts species from where the four $R$. pseudosolanacearum strains were isolated: Mandevilla boliviensis 'Brides Cascade', Osteospermum sp. 'Margarita Purple 102/100 TY', southern highbush blueberry Vaccinium corymbosum 'Arcadia', hybrid tea rose Rose spp. 'Moonlight Romantica'. Three different species of rose were added to the host specificity study to observe differences in specificity: grandiflora rose 'American Magic', miniature rose 'Mandarin Sunblaze', and knock out rose 'Double Red'. Tomato Solanum lycopersicum 'Walter' was added as a positive control since all RSSC strains cause disease to tomato. Pathogenicity tests results on the described hosts when inoculated with P781, P824, PD7123, and UW757 are shown in Table 2. All strains were pathogenic and highly virulent on tomato 'Walter' as expected confirming that the strains are pathogenic. Both P824 (blueberry strain) and PD7123 (tea rose strain) were pathogenic on blueberry 'Arcadia' and tea rose 'Moonlight Romantica', while P781 (mandevilla strain) and UW757 (osteospermum strain)

Table 2 Pathogenicity tests on eight selected hosts. Ten plants were subsequently inoculated with $10^{6} \mathrm{cfu}$ of the pathogen on an opened wound above the soil line and incubated for 45 days were not. Although phylogenetically P824 and PD7123 genomes are more dissimilar than the average ANI \% for phylotype I (Fig. 1B), they had the same specificity in most of the hosts tested. Strains were more aggressive on their original hosts with a higher disease incidence (Table 2). The southern high bush cultivar 'Arcadia' was very susceptible to both strains. Slight differences in visual symptoms on blueberry were observed between the two strains. Both produced scorch symptoms, red foliage and resulted in wilting of actively growing tips (Fig. 2A). In addition, PD7123 (tea rose strain) produced bright red vascular venial discoloration in blueberry young leaves (Fig. 2B). Asymptomatic infections occurred on knock-out roses and no infection was found with the miniature roses by any of the strains. Consistently, P781 and UW757 did not cause disease in blueberry or any of the roses tested, however were able to survive in the stem of $20 \%$ of the blueberry 'Arcadia' tested and $7 \%$ and $13 \%$ respectively in tea rose 'Moonlight Romantica'. Only P781 was able to survive asymptomatically in $17 \%$ of the Grandiflora Rose 'American Magic' plants tested, and only UW757 was able to survive in $7 \%$ of the Knockout Rose 'Double Red'. Only the mandevilla strain (P781) was found to infect and produce symptoms on mandevilla, although, infection rate was only $20 \%$ (Table 2 ). In previous experiments P781 but not UW757 did cause symptoms in mandevilla 'Bride's cascade' plants at a higher rate (unpublished results). The previous experiments were performed in greenhouses where the temperature was always above $28{ }^{\circ} \mathrm{C}$ compared with

before scoring disease symptoms. The first column indicates the source host where each strain was isolated.

\begin{tabular}{|c|c|c|c|c|c|c|c|c|c|}
\hline Original host & Strain ID & $\begin{array}{l}\text { Tomato } \\
\text { 'Walter' }\end{array}$ & $\begin{array}{l}\text { Blueberry } \\
\text { 'Arcadia' }\end{array}$ & $\begin{array}{l}\text { Man- } \\
\text { devilla } \\
\text { 'Brides } \\
\text { Cas- } \\
\text { cade' }\end{array}$ & $\begin{array}{l}\text { Tea Rose } \\
\text { 'Moonlight } \\
\text { Romantica' }\end{array}$ & $\begin{array}{l}\text { Gran- } \\
\text { diflora } \\
\text { Rose } \\
\text { 'Ameri- } \\
\text { can } \\
\text { Magic' }\end{array}$ & $\begin{array}{l}\text { Knock Out } \\
\text { Rose 'Double } \\
\text { Red' }\end{array}$ & $\begin{array}{l}\text { Miniature } \\
\text { Rose } \\
\text { 'Mandarin } \\
\text { Sunblaze' }\end{array}$ & $\begin{array}{l}\text { Osteospermum } \\
\text { 'Margarita } \\
\text { purple' }\end{array}$ \\
\hline
\end{tabular}

\begin{tabular}{|c|c|c|c|c|c|c|c|c|c|}
\hline \multirow[b]{2}{*}{ Blueberry } & \multirow[b]{2}{*}{ P824 } & \multicolumn{8}{|c|}{ Percentage of wilted plants (\%) } \\
\hline & & 97 & 97 & 0 & 30 & 7 & $10^{*}$ & 0 & 0 \\
\hline Tea rose & PD7123 & 97 & 90 & 0 & 77 & 57 & $23 *$ & 0 & 93 \\
\hline Mandevilla & P781 & 100 & $20 *$ & 20 & $7 *$ & $17 *$ & 0 & 0 & 97 \\
\hline $\begin{array}{l}\text { Osteosper- } \\
\text { mum }\end{array}$ & UW757 & 93 & $20 *$ & 0 & $13 *$ & 0 & $7 *$ & 0 & 100 \\
\hline
\end{tabular}

*Percentage of asymptomatic plants with viable populations of $R$. pseudosolanacearum in the stem after 45 days 
Fig. 2 Bacterial wilt symptoms in southern highbush blueberry 'Arcadia' when inoculated with $R$. pseudosolanacearum strains (a) P824, (b) PD7123

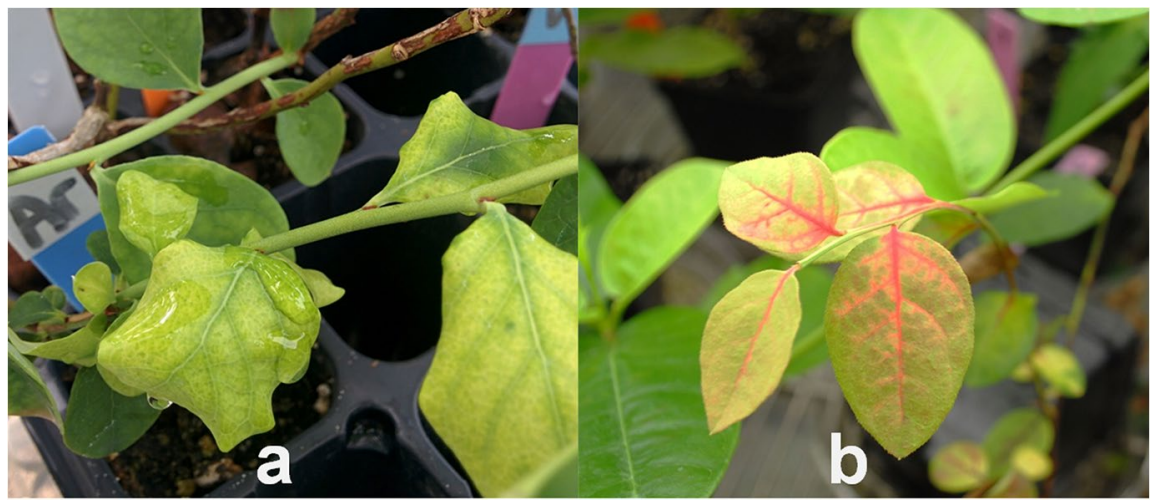

the experiments for this work in controlled chambers at $28{ }^{\circ} \mathrm{C} / 20{ }^{\circ} \mathrm{C}$ on a $12 \mathrm{~h} / 12 \mathrm{~h}$ day/night cycle. In similar works the difference in temperature was also an important factor on disease severity; however, it did not affect pathogenicity (Tjou-Tam-Sin et al., 2017). Visual symptoms on mandevilla 'Bride's Cascade' and osteospermum "Margarita Purple' infected with P781 also differed. Symptoms on mandevilla 'Bride's Cascade' start with yellowing of the leaves (Fig. 3A) becoming scorched and necrotic as the infection advances. Usually, the infection starts on one of the runners and slowly extends to the others. On osteospermum the symptoms are more like to the ones on solanaceous plants. It starts with wilting of side leaves until all the plant is wilted (Fig. 3B).

P781 (mandevilla), UW757 (osteospermum), and PD7123 (tea rose) were pathogenic to osteospermum. In contrast, P824 (blueberry) was non-pathogenic (Table 2).

In summary, both P824 and PD7123 were specifically pathogenic to blueberry 'Arcadia' and hybrid tea rose 'Moonlight Romantica', P781 was specifically pathogenic to mandevilla 'Bride's Cascade', and P824 was specifically non-pathogenic to osteospermum 'Margarita Purple'.

T3Es prediction and curated repertoire

In Silico predicted T3E using the Ralsto T3E web software (Peeters et al., 2013) are shown in its original form in Online Resource 2A. After a manual curation preliminary candidate virulence and avirulence genes were selected and PCR and sequencing validation were performed on the preliminary candidates as explained below to yield the curated T3E repertoire (Online Resource 2B).

The Ralsto T3E software uses the multifasta genome files as input to predict the gene sequence and translated protein sequence, making it independent of the annotation system. Since draft genomes are fragmented in scaffolds and contigs, there are nonsequenced gaps, and gene annotations could differ
Fig. 3 Bacterial wilt symptoms when inoculated with $R$. pseudosolanacearum P781 in a) mandevilla 'Bride's Cascade' b) osteospermum 'Margarita Purple'

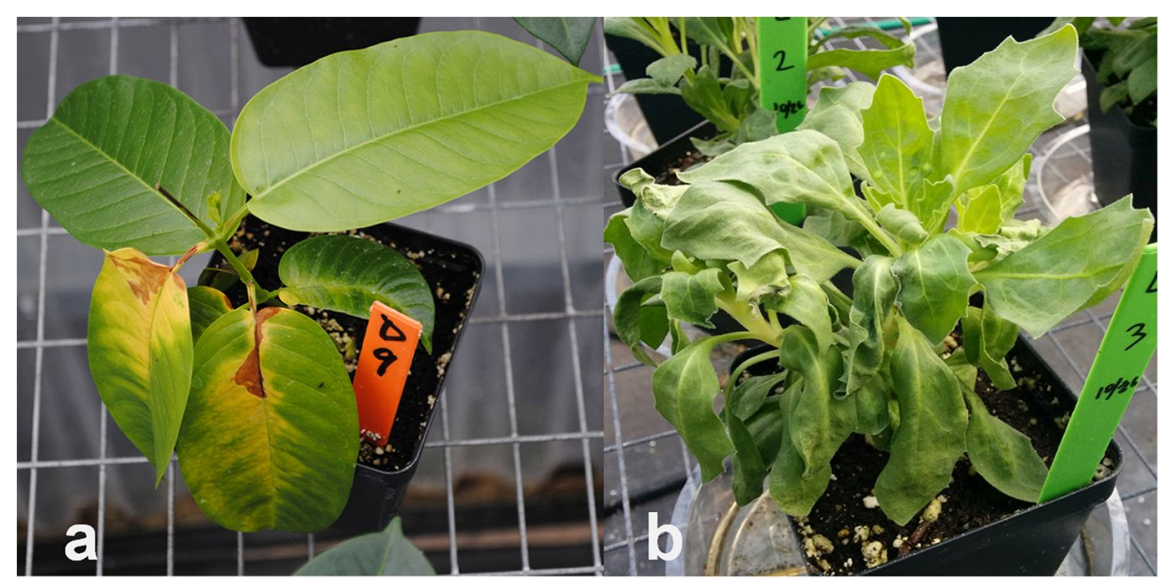


among genomes, a manual curation was performed on the automated Ralsto T3E predictions as described in Materials and Methods. Comparisons, between NCBI BLAST searches, the orthologues files from MAUVE alignment and the predicted proteins by Ralsto T3E were used to confirm sequences or join sequences spanning contiguous contigs.

According to the Ralsto T3E web page, 118 effector families have been identified in the RSSC. In our comparison and after manual curation there were 37 families not represented in any of the four genomes compared (Online Resource 2B), including RipC2 which was a pseudogene in all 4 strains, therefore considered not represented. Sixty-two core effector families were found in all four strains. Only 19 families were distributed heterogeneously among the strains (Fig. 5). There was one effector present only in PD7123. No unique (strain specific) effectors were present in P824 or P781, while there were two unique effectors present in UW757. Only two effector families were represented by paralog sets of effectors, RipJ and RipAC (Online Resource 2B). The disrupted or frameshifted gene sequences were annotated as pseudogenes and are not counted in the Venn diagram. The genes not annotated in the public databases, or with modified annotation are indicated in Online Resource 2B. Sequenced CDS not annotated in the genomes were deposited in the NCBI Genbank database. Modified annotations and sequenced CDS for this work accession numbers can be found in Online Resource 3.

Selection of candidate T3E that confer host specificity and validation of candidate genes sequences by PCR and Sanger sequencing

As described in the previous section, the complete list of manually curated T3E of the four strains compared are listed in Online Resource 2B. The table identifies changes in annotations due to manual curation and indicates the preliminary candidates to virulence and avirulence factors. The differences between T3Es repertoires were compared with the host specificity results in order to formulate two hypotheses for the selection of candidate T3Es. Hypothesis 1 assumes that the effectors behave as virulence factors that inhibit or overcome defense responses and expand the host range. Hypothesis 2 assumes that the effectors behave as avirulence factors and are recognized by the host restricting the host range. For host specificity to mandevilla two putative avirulence T3Es (RipAZ1 and RS_T3E_Hyp8) were identified because they are absent only in P781 (Online resource 2B). In contrast, for host specificity to osteospermum only one putative virulence T3E was identified (RipS1) because is absent only in P824. Applying the hypotheses for host specificity to blueberry and tea rose was more complicated because strains P824 and PD7123 are both pathogenic to both hosts, then two cases were considered: 1) A case where P824 and PD7123 are pathogenic due to shared effectors absent in P781 and UW757. Two candidate virulence effectors (RipG1, RipF1) were identified (Online resource 2B), whereas three candidates missing in both PD7123 and P824 for avirulence were identified (RipT, RipBE, RS T3E_hyp14); and 2) a case where the effectors for each strain are different. RS_T3E_hyp7 only present in PD7123 may explain its pathogenicity in blueberry and rose, whereas two putative avirulence T3Es (RipE2, RipP3) only present in UW757, may explain why UW757 is non-pathogenic in blueberry and rose (Online Resource 2B).

To validate those candidates, primers were designed (Online Resource 1) and PCR was performed on the four strains. The gels confirm the presence of a truncated sequence for RipG1 (Online Resource 4-1) in P781, suggesting an interrupted gene by deletion. RipF1 was eliminated as candidate since the PCR produced a sequence for P781 not predicted because of assembly error (Online Resource 4-2). Rip BE and Rs_T3E_hyp14 were originally identified as candidates for hypothesis 2 as avirulence factors recognized by blueberry and tea rose, however unexpectedly there was a PCR product in P824 (Online Resource 4-3, and 4-4 respectively) and were eliminated as candidates, while RipT was present only in P781 and UW757 as expected (Online Resource 4-5). For mandevilla specificity, RipAZ1 was present in all the strains (Online Resource 4-6). For osteospermum specificity, RipS1 was present in all strains except P824 as expected (Online Resource 4-7). The sequenced PCR fragments for RipG1 were identical to the expected sequences retrieved from NCBI, confirming that P781 is a pseudogene P781 and UW757. The unexpected sequences for RipBE and Rs_T3E_hyp14 in P824 were identical to the corresponding sequences in P781 and UW757. For 
mandevilla RipAZ1, sequence in P781 was confirmed as a pseudogene and a valid avirulence candidate for mandevilla specificity. RipS1 sequences were identical to the expected sequences retrieved from NCBI in P781, UW757, and PD7123. The sequence was absent from P824, confirming RipS1 as a candidate for osteospermum specificity. The rest of the selected candidate sequences were identical to NCBI confirming their eligibility or elimination (Online Resource 4-8 to 4-12). Presence or absence or bands and sequencing results are summarized in Table 3.

Significant differences in protein structure can alter the function of $\mathrm{T} 3 \mathrm{E}$, allowing them to be recognized by the host or not. Sequences of each effector family were compared for the 4 strains studied. Protein structure was considered altered when orthologous sequences were below $70 \%$ similarity. Based on this criteria RS_T3E_hyp6 was added as a candidate virulence factor for blueberry and rose since it was absent in P781, and the sequence similarity was $65 \%$ in UW757 compared with P824 and PD7123. Alternatively, if RS_T3E_ hyp6 conserves its function in UW757 despite the difference, this effector could be considered as a candidate avirulence factor for mandevilla, since it would be absent only in P781. Table 4 presents a summary with the final candidates after sequence validation

\section{Discussion}

Previous works attempted to associate the pan-T3E repertoire of diverse populations of Ralstonia solanacearum with host range, gave mixed results (Hajri et al., 2009; Baltrus et al., 2011; Cellier et al., 2012; Ailloud et al., 2015). Phylotype I strains were not included in these studies because they were not evidently associated with other than Solanaceous hosts, nor were they part of evidently identified ecotypes. Trying to identify specific strain-host (at variety level) interactions is very complex if the analysis is done at species level due to the large $\mathrm{T} 3 \mathrm{E}$ repertoire of the species complex, the diversity of the strains, and the specificity of T3E and resistance genes interactions with different varieties of the same host species. Thus, a more specific approach where several of these variables are controlled could be most useful to associate T3E with particular hosts (host specificity). This is the first work that addresses association of T3Es with host specificity in Phylotype I strains, now included in the Ralstonia pseudosolanacearum species. In this work, we compared four genomes of phylogenetically closely related strains with different host ranges. Our working hypothesis was that phylogenetically closely related strains would have a similar T3E repertoire, reducing the number of candidates that determine their host range. We verified that phylotype I strains are very conserved evidenced for ANI \% ranging from $98.84 \%$ to 99.99 for

Table 3. Validation of selected T3Es by PCR and sequencing: Expected size PCR met: PG=pseudogene, C=complete, $\mathrm{A}=\mathrm{Absent}$

\begin{tabular}{|c|c|c|c|c|c|c|c|c|}
\hline T3E & P781 & & UW757 & & P824 & & PD7123 & \\
\hline & Expected PCR & $\begin{array}{l}\text { protein } \\
\text { sequence }\end{array}$ & Expected PCR & $\begin{array}{l}\text { protein } \\
\text { sequence }\end{array}$ & Expected PCR & $\begin{array}{l}\text { protein } \\
\text { sequence }\end{array}$ & $\begin{array}{l}\text { Expected PCR } \\
\text { size }\end{array}$ & $\begin{array}{l}\text { protein } \\
\text { sequence }\end{array}$ \\
\hline RipG1 & Present & PG & Present & PG & Present & $\mathrm{C}$ & Present & $\mathrm{C}$ \\
\hline RipF1 & Present & $\mathrm{C}$ & Present & PG & Present & $\mathrm{C}$ & Present & $\mathrm{C}$ \\
\hline RipBE & Present & $\mathrm{C}$ & Present & $\mathrm{C}$ & Present & $\mathrm{C}$ & Absent & A \\
\hline $\begin{array}{c}\text { Rs_T3E_ } \\
\text { hyp14 }\end{array}$ & Present & $\mathrm{C}$ & Present & $\mathrm{C}$ & Present & $\mathrm{C}$ & Absent & PG \\
\hline RipT & Present & $\mathrm{C}$ & Present & $\mathrm{C}$ & Absent & PG & Absent & A \\
\hline RipAZ1 & Present & PG & Present & $\mathrm{C}$ & Present & $\mathrm{C}$ & Present & $\mathrm{C}$ \\
\hline RipS1 & Present & $\mathrm{C}$ & Present & $\mathrm{C}$ & Absent & A & Present & $\mathrm{C}$ \\
\hline RipAX1 & Present & PG & Present & $\mathrm{C}$ & Present & $\mathrm{C}$ & Present & PG \\
\hline RipAR & Present & PG & Present & $\mathrm{C}$ & Present & PG & Present & $\mathrm{C}$ \\
\hline Rs_T3E_hyp8 & Present & PG & Present & $\mathrm{C}$ & Present & $\mathrm{C}$ & Present & $\mathrm{C}$ \\
\hline Rs_T3E_hyp7 & $\begin{array}{l}\text { Not expected } \\
\text { size }\end{array}$ & PG & Absent & A & Absent & A & Present & $\mathrm{C}$ \\
\hline
\end{tabular}


Table 4. Summary table of candidate T3E selected for host specificity

\begin{tabular}{|c|c|c|}
\hline HOST & Candidate Virulence & Candidate avirulence \\
\hline $\begin{array}{l}\text { Blueberry } \\
\text { 'Arcadia' }\end{array}$ & $\begin{array}{l}\text { Present in P824 and PD7123 } \\
\text { RipG1 } \\
\text { RS_T3E_Hyp6 (S) } \\
\text { Present in PD7123 } \\
\text { Rsp_T3E_Hyp7 }\end{array}$ & $\begin{array}{l}\text { Present in P781 and UW757 } \\
\text { RipT } \\
\text { Present in UW757 } \\
\text { Rip E2 } \\
\text { Rip P3 }\end{array}$ \\
\hline $\begin{array}{l}\text { Tea Rose } \\
\text { 'Moonlight Romantica' }\end{array}$ & $\begin{array}{l}\text { Present in P824 and PD7123 } \\
\text { RipG1 } \\
\text { RS_T3E_Hyp6 (S) } \\
\text { Present in PD7123 } \\
\text { Rsp_T3E_Hyp7 }\end{array}$ & $\begin{array}{l}\text { Present in P781 and UW757 } \\
\text { RipT } \\
\text { Present in UW757 } \\
\text { Rip E2 } \\
\text { Rip P3 }\end{array}$ \\
\hline $\begin{array}{l}\text { Mandevilla } \\
\text { 'Brides Cascade' }\end{array}$ & $\begin{array}{l}\text { Present in P781 only } \\
\text { None }\end{array}$ & $\begin{array}{l}\text { Present in P824, UW757, PD7123 } \\
\text { RipAZ1 } \\
\text { RS_T3E_Hyp8 } \\
\text { RS_T3E_Hyp6 (S) }\end{array}$ \\
\hline Osteospermum 'Margarita purple' & $\begin{array}{l}\text { Present in P781, UW757, PD7123 } \\
\text { RipS1 }\end{array}$ & $\begin{array}{l}\text { Present in P824 only } \\
\text { None }\end{array}$ \\
\hline
\end{tabular}

(S) indicates low similarity to other orthologs

the 28 phylotype I genomes analyzed (Fig. 2C). The more distant genome of the four genomes compared was PD7123 with an ANI\% of 99.03\% compared with P781 (Fig. 2C), and by the high percentage of core orthologues (3980) (Fig. 4) compared with an average of 2000-2500 in previous and more diverse pan-genomic comparisons (Remenant et al., 2010; Bocsanczy et al., 2017). Diverse evolutionary mechanisms can influence the susceptibility or resistance of specific hosts to specific strains (Rohmer et al., 2004). The most influential mechanisms include horizontal transfer of T3E to new strains (Hajri et al., 2009), loss of effectors that do not serve a function in a specific environment (Dillon et al., 2019) and/or recognition by specific hosts resistance genes (Deslandes et al., 2002; Oh and Martin, 2011). Thus, comparing closely related $R$. pseudosolanacearum strains facilitates exploring the interaction between specific hosts and strains. Of 81 effectors present in one or more of the four strains 62 (76.5\%) were core effectors (Fig. 5), confirming the closeness of their T3E repertoire. Only 19 effectors were distributed heterogeneously. Ralstonia strains can encounter new hosts in different situations. When in the field new crops are planted in endemic soils infested with the pathogen or in a close recirculation system where the pathogen is present, diseases emerge as is in the case of blueberry. Alternatively, plants grown in greenhouses such as ornamentals (e.g., rose, mandevilla, osteospermum) may encounter new strains that come in latent

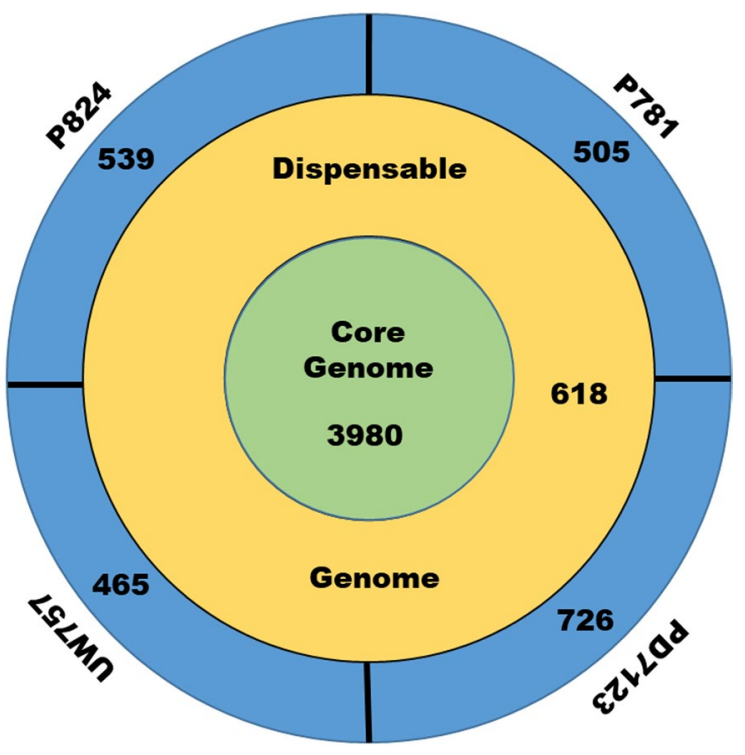

Fig. 4 Pangenome of strains P781, P824, UW757 and PD7123. Diagram shows the number of orthologous genes present in the pangenome of the compared strains. The outer circle indicates genes that are unique to the strain in the corresponding section. The middle circle indicates the number of genes that are present in at least two of the compared genomes and at most three genomes. The inner circle indicates the number of orthologues present in all the genomes (core genome)

infections in other hosts. In both cases hosts develop the disease due to the ample repertoire of T3Es and the recent exposure of the host, which likely will not 


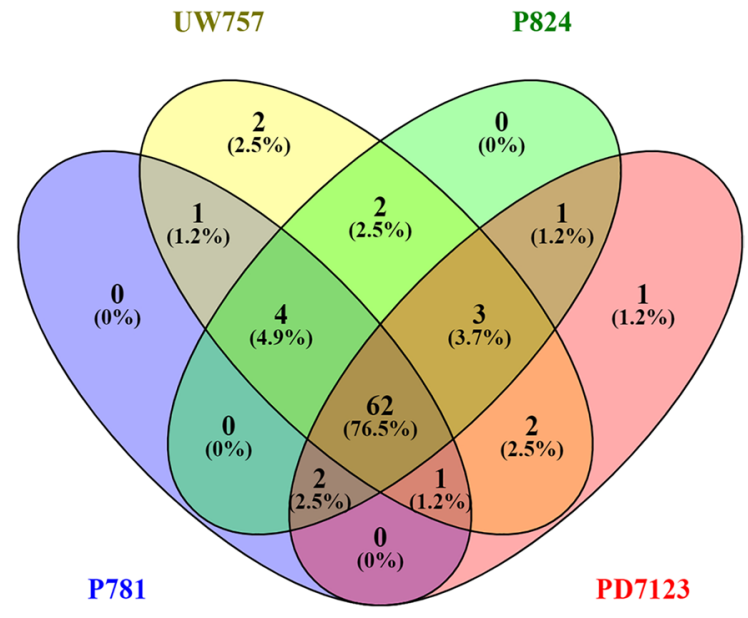

Fig. 5 Distribution of T3Es families present in the genomes of compared strains. Venn diagram shows the number and percentages (in parenthesis) of T3Es orthologs families present in one or more genomes. Diagram was produced with Venny 2.1.0 software (https://bioinfogp.cnb.csic.es/tools/venny/ )

have built-in defenses. In that case, if T3Es are not recognized by the host (Angot et al., 2006; Macho, 2016) will function as virulence factors. After sequence validation, we identified RipG1 as a likely virulence factor in blueberry and rose. In P781 and UW757, RipG1 are pseudogenes due to the presence of a frameshift in position 968 after the first nucleotide of the Open Reading Frame (ORF) that truncates the proteins. RipG1 is a Gala protein 1 homolog (Angot et al., 2006). Gala is a family of seven effectors that contain both F-Box and LRR domains. It was shown that the F-Box domain of GALA proteins interacts with Skip1 subunits (part of the E3 ubiquitin ligase complex) in host plants interfering with their host ubiquitin/proteasome pathway, an important pathway for many developmental processes and stress responses (Angot et al., 2006). Recently, was shown that GALA1 (RipG1) from $R$. pseudosolanacearum GMI1000 expressed in Nicotiana benthamiana localized to the chloroplasts where it reduced significantly the flg22-induced calcium burst, and when expressed in Arabidopsis it changed the expression of SA-responsive genes following flg-22 treatment and increased susceptibility to Pseudomonas syringae Pto DC3000 (Medina-Puche et al., 2020) acting as a virulence factor. RipG1 protein sequence in GMI1000 similarity to the sequences in P824 and PD7123 is 99\%, (only three AA in 661) supporting the hypothesis of RipG1 as virulence factor. Moreover, although there is a high redundancy of GALA proteins in the RSSC, GALA diversification contributes to $R$. solanacearum adaptation to diverse plant hosts (Remigi et al., 2011), Gala 7 alone was required to cause disease in Medicago truncatula plants acting as a host specificity factor (Angot et al., 2006) and it was shown that RipG7 undergoes diversification of certain AA from different strains presumably to adapt to different hosts (Wang et al., 2016). Our results show that strains P781 and UW757 are capable of invading the vascular system of blueberry and rose plants stems, but infections remain symptomless (Table 2). Alternatively, T3Es act as avirulence proteins inducing resistance in plants. Under this hypothesis we identified RipT as a candidate avirulence factor in P781 and UW757 that would restrict their host range in blueberry 'Arcadia' and tea rose 'Moonlight Romantica'. RipT belongs to the YopT (Yersinia Outer protein) superfamily of cysteine proteases (Shao et al., 2002). These proteins have a triad of conserved amino acids but, the roles and targets of the different homologs of YopT are different (Figaj et $a l ., 2019)$. Proteases are often recognized by resistance proteins in the host (Ade et al., 2007; Bocsanczy et al., 2012) and identified as avirulence genes. Host specificity for mandevilla seems to be determined by avirulence factors, since no candidate virulence factors were identified. RipAZ1, a likely candidate avirulence factor, is present in all the strains studied, although the gene sequence in P781 has undergone changes that alters the aminoacids structure. The loss of this protein possibly avoids recognition by the host defense system and makes P781 virulent to mandevilla. RipAZ1 was identified as an avirulence determinant in Solanum Americanum (Moon et al., 2021) strengthening our hypothesis. For osteospermum RipS1 was identified as a putative virulence factor that is not present in P824. RipS1 belongs to the RipS multigene family. It contains SKWP repeats domains in different numbers. Each SKWP repeat domain contains 42-45 aminoacids starting with Ser, Lys, Trp and Pro, hence the name (Mukaihara and Tamura, 2009). Each RipS contains 12-18 repeats in the N-terminus region. In RSSC eight RipS (1-8) proteins have been described (Peeters et al., 2013). RipS family has been associated with bacterial fitness in eggplant (Chen et al., 2018). RipS1 was shown among other effectors in strain RS1000 (phylotype I) to weakly 
(70\%) suppress fl22-induced ROS burst when transiently expressed in $N$. benthamiana leaves by agroinfiltration (Nakano and Mukaihara, 2019b), and RipS1 and RipS4 were shown to contribute to virulence in eggplant (Chen et al., 2021), supporting the virulence function hypothesis.

Significant differences in protein structure could also affect the function of a T3E. We found RS_ T3E_hyp6 has only $65 \%$ similarity with the orthologues in P824, and PD7123 while it is absent in $\mathrm{P} 781$. In this case assuming that the function is lost in UW757, the effector could be considered a virulence factor for blueberry and rose. Alternatively, if the function in UW7575 is conserved, it could be considered an avirulence factor for mandevilla. Some of the core effectors could also be candidates if their protein conformation is different, however this is an unlikely possibility since the core effectors had a sequence similarity over $98 \%$ with few exceptions, with similarities over $80 \%$ (Online Resource 2B), confirming the genomic closeness of the studied Rps strains. We tested pathogenicity on four host species. Southern highbush blueberry (Vaccinium corymbosum) cv. "Arcadia" belong to the order Ericales, tea hybrid rose to the order Rosales, Mandevilla to the order Gentianales and Osteospermum to the order Asterales. Interestingly, P824 and PD7123, two strains found in two different continents and in two plants that belong to different orders were capable of infecting both blueberry and tea rose hosts. Families of orthologous effectors can undergo changes in specific strains by degradation (pseudogene), when meet hosts that recognize the effector to adapt to their hosts/environment. When in contact with a new host, the same strains might lose virulence or become nonpathogenic due to the loss of those effectors. The progressive resistance of different rose species to P824 and PD7123 evidenced another mechanism of resistance. These strains were not able to cause disease in 'Double Knock out' and miniature roses and showed decreased susceptibility in Grandiflora roses. Susceptibility of rose cultivars appeared to be negatively correlated with flower size. This is similar with results previously reported for bacterial wilt resistance and size of tomato (Acosta et al., 1964; Walter, 1967; Opeña, 1990; Wang et al., 1998). It is probable that flower size could be genetically linked to resistance clusters in plants genomes. Although genomic relationships between hybrid roses is complicated due to extensive breeding of many species and different ploidy, miniature roses are completely resistant to all $R$. pseudosolanacearum strains tested and probably the defense responses involve Pattern Triggered Immunity (PTI) also related to non-host immunity (Jones and Dangl, 2006; Zipfel, 2014). Similarly, hybrids of mandevilla s.p. can have different susceptibilities to the same strains. The authors plan to test these hypotheses by functionally characterizing and determining the mechanisms of action of the candidate effectors identified in this work. This work presents a set of T3E curated sequences in four Rps strains, a reduced number of candidates to virulence and avirulence factors and contributes to the understanding of host specificity in Ralstonia pseudosolanacearum.

Data availability Data is available either in supplementary material or at Genbank. Strains are available from the authors collections upon request

\section{Code availability Not Applicable}

Author's contributions AMB and DJN conceived the project and did experiments. AMB analyzed data and wrote the manuscript. MVB, JVW and PB provided strains, sequences and analyzed data, edited the manuscript, and provided feedback

\section{Declarations}

Conflict of Interest The authors have no relevant financial or non-financial interests to disclose

Research involving Human Participants and/or Animals This work does not involve Human or animal participants

Informed Consent Not applicable since this work does not involve human participants

Consent for publication Not applicable

Open Access This article is licensed under a Creative Commons Attribution 4.0 International License, which permits use, sharing, adaptation, distribution and reproduction in any medium or format, as long as you give appropriate credit to the original author(s) and the source, provide a link to the Creative Commons licence, and indicate if changes were made. The images or other third party material in this article are included in the article's Creative Commons licence, unless indicated otherwise in a credit line to the material. If material is not included in the article's Creative Commons licence and your intended use is not permitted by statutory regulation or exceeds 
the permitted use, you will need to obtain permission directly from the copyright holder. To view a copy of this licence, visit http://creativecommons.org/licenses/by/4.0/.

\section{References}

Acosta, J.C., Gilbert, J. \& Quiñon, V.L., 1964. Heritability of bacterial wilt resistance in tomato. In: American society for horticultural science, proceedings.

Ade, J., DeYoung, B.J., Golstein, C. \& Innes, R.W., (2007). Indirect activation of a plant nucleotide binding siteleucine-rich repeat protein by a bacterial protease. Proc Natl Acad Sci U S A, 104(7): 2531-2536. Available from https://www.ncbi.nlm.nih.gov/pubmed/17277084. DOI https://doi.org/10.1073/pnas.0608779104.

Ailloud, F., Lowe, T., Cellier, G., Roche, D., Allen, C. \& Prior, P., (2015). Comparative genomic analysis of ralstonia solanacearum reveals candidate genes for host specificity. BMC Genomics, 16: 270. Available from https://www.ncbi.nlm.nih.gov/pubmed/25888333. DOI https://doi.org/10.1186/s12864-015-1474-8.

Altschul, S.F., Gish, W., Miller, W., Myers, E.W. \& Lipman, D.J., (1990). Basic local alignment search tool. J Mol Biol, 215(3): 403-410. Available from https://www.ncbi. nlm.nih.gov/pubmed/2231712. DOI https://doi.org/10. 1016/S0022-2836(05)80360-2.

Angot, A., Peeters, N., Lechner, E., Vailleau, F., Baud, C., Gentzbittel, L., Sartorel, E., Genschik, P., Boucher, C. \& Genin, S., (2006). Ralstonia solanacearum requires f-box-like domain-containing type iii effectors to promote disease on several host plants. Proc Natl Acad Sci U S A, 103(39): 14620-14625. Available from https:// www.ncbi.nlm.nih.gov/pubmed/16983093. DOI https:// doi.org/10.1073/pnas.0509393103.

Baltrus, D.A., Nishimura, M.T., Romanchuk, A., Chang, J.H., Mukhtar, M.S., Cherkis, K., Roach, J., Grant, S.R., Jones, C.D. \& Dangl, J.L., (2011). Dynamic evolution of pathogenicity revealed by sequencing and comparative genomics of 19 pseudomonas syringae isolates. PLoS Pathog, 7(7): e1002132. Available from https:// www.ncbi.nlm.nih.gov/pubmed/21799664. DOI https:// doi.org/10.1371/journal.ppat.1002132.

Bergsma-Vlami, M., van de Bilt, J.L.J., Tjou-Tam-Sin, N.N.A., Westenberg, M., Meekes, E.T.M., Teunissen, H.A.S. \& Van Vaerenbergh, J., (2018). Phylogenetic assignment of ralstonia pseudosolanacearum (ralstonia solanacearum phylotype i) isolated from rosa spp. Plant Dis, 102(11): 2258-2267. Available from https://www. ncbi.nlm.nih.gov/pubmed/30192708. DOI https://doi. org/10.1094/PDIS-09-17-1345-RE.

Bocsanczy, A.M., Espindola, A.S. \& Norman, D.J., (2019). Whole-genome sequences of ralstonia solanacearum strains p816, p822, and p824, emerging pathogens of blueberry in florida. Microbiol Resour Announc, 8(3). Available from https://www.ncbi.nlm.nih.gov/pubmed/ 30687821. DOI https://doi.org/10.1128/MRA.01316-18.

Bocsanczy, A.M., Huguet-Tapia, J.C. \& Norman, D.J., (2017). Comparative genomics of ralstonia solanacearum identifies candidate genes associated with cool virulence. Front Plant Sci, 8: 1565. Available from https://www.ncbi.nlm.nih.gov/pubmed/28955357. DOI https://doi.org/10.3389/fpls.2017.01565.

Bocsanczy, A.M., Schneider, D.J., DeClerck, G.A., Cartinhour, S. \& Beer, S.V., (2012). Hopx1 in erwinia amylovora functions as an avirulence protein in apple and is regulated by hrpl. J Bacteriol, 194(3): 553-560. Available from https://www.ncbi.nlm.nih.gov/pubmed/22123 252. DOI https://doi.org/10.1128/JB.05065-11.

Bocsanczy, A.M., Yuen, J.M.F., Palmateer, A.J. \& Norman, D.J., (2014). Comparative genomics of ralstonia solanacearum strain p781 that infects mandevilla and dipladenia plants. Phytopathology, 104(11): 16-16. Available from $<$ Go to ISI $>$ ://WOS:000346303300089.

Castillo, J.A. \& Greenberg, J.T., (2007). Evolutionary dynamics of ralstonia solanacearum. Appl Environ Microbiol, 73(4): 1225-1238. Available from https://www.ncbi.nlm. nih.gov/pubmed/17189443. DOI https://doi.org/10.1128/ AEM.01253-06.

Cellier, G., Remenant, B., Chiroleu, F., Lefeuvre, P. \& Prior, P., (2012). Phylogeny and population structure of brown rot- and moko disease-causing strains of ralstonia solanacearum phylotype ii. Appl Environ Microbiol, 78(7): 2367-2375. Available from https://www.ncbi.nlm.nih.gov/ pubmed/22286995. DOI https://doi.org/10.1128/AEM. 06123-11.

Chang, J.H., Urbach, J.M., Law, T.F., Arnold, L.W., Hu, A., Gombar, S., Grant, S.R., Ausubel, F.M. \& Dangl, J.L., (2005). A high-throughput, near-saturating screen for type iii effector genes from pseudomonas syringae. Proc Natl Acad Sci U S A, 102(7): 2549-2554. Available from https://www.ncbi.nlm.nih.gov/pubmed/15701698. DOI https://doi.org/10.1073/pnas.0409660102.

Chen, L., Lei, N., Kiba, A., Hikichi, Y. \& Ohnishi, K., (2021). Contribution of rips type iii effector family of ralstonia solanacearum japanese strain oe1-1 to disease development in eggplant. Journal of General Plant Pathology, 87(2): 77-82. Available from <Go to ISI >:// WOS:000608382700001. DOI https://doi.org/10.1007/ s10327-020-00977-5.

Chen, L., Li, J., Shirota, M. \& Ohnishi, K., (2018). Analysis of the skwp effectors to bacterial fitness in host plant by a novel competition assay. Acta Microbiologica Sinica, 58(3): 432-442. Available from https://doi.org/10.13343/j. cnki.wsxb.20170221.

Darling, A.C., Mau, B., Blattner, F.R. \& Perna, N.T., (2004). Mauve: Multiple alignment of conserved genomic sequence with rearrangements. Genome Res, 14(7): 13941403. Available from https://www.ncbi.nlm.nih.gov/pubmed/15231754. DOI https://doi.org/10.1101/gr.2289704.

Deslandes, L., Olivier, J., Theulieres, F., Hirsch, J., Feng, D.X., Bittner-Eddy, P., Beynon, J. \& Marco, Y., (2002). Resistance to ralstonia solanacearum in arabidopsis thaliana is conferred by the recessive rrs1-r gene, a member of a novel family of resistance genes. Proc Natl Acad Sci U S A, 99(4): 2404-2409. Available from https://www.ncbi. nlm.nih.gov/pubmed/11842188. DOI https://doi.org/10. 1073/pnas.032485099.

Dillon, M.M., Almeida, R.N.D., Laflamme, B., Martel, A., Weir, B.S., Desveaux, D. \& Guttman, D.S., (2019). 
Molecular evolution of pseudomonas syringae type iii secreted effector proteins. Front Plant Sci, 10: 418. Available from https://www.ncbi.nlm.nih.gov/pubmed/31024 592. DOI https://doi.org/10.3389/fpls.2019.00418.

Drotleff, L., 2018. Cuttings producers improve quality and focus on streamlining the supply chain. In: Greenhouse Grower.

Fegan, M., and P. Prior, (2005). How complex is the "ralstonia solanacearum species complex". In: Bacterial wilt disease and the ralstonia solanacearum species complex, P. P. C. Allen, and A. C. Hayward, (Ed.). APS Press, Madison, WI: pp: 449-462.

Figaj, D., Ambroziak, P., Przepiora, T. \& Skorko-Glonek, J., (2019). The role of proteases in the virulence of plant pathogenic bacteria. Int J Mol Sci, 20(3). Available from https://www.ncbi.nlm.nih.gov/pubmed/30720762. DOI https://doi.org/10.3390/ijms20030672.

Guidot, A., Prior, P., Schoenfeld, J., Carrere, S., Genin, S. \& Boucher, C., (2007). Genomic structure and phylogeny of the plant pathogen ralstonia solanacearum inferred from gene distribution analysis. J Bacteriol, 189(2): 377-387. Available from https://www.ncbi.nlm.nih.gov/pubmed/ 17085551. DOI https://doi.org/10.1128/JB.00999-06.

Hajri, A., Brin, C., Hunault, G., Lardeux, F., Lemaire, C., Manceau, C., Boureau, T. \& Poussier, S., (2009). A "repertoire for repertoire" hypothesis: Repertoires of type three effectors are candidate determinants of host specificity in xanthomonas. PLoS One, 4(8): e6632. Available from https://www.ncbi.nlm.nih.gov/pubmed/19680562. DOI https://doi.org/10.1371/journal.pone.0006632.

Hong, J.C., Norman, D.J., Reed, D.L., Momol, M.T. \& Jones, J.B., (2012). Diversity among ralstonia solanacearum strains isolated from the southeastern united states. Phytopathology, 102(10): 924-936. Available from https://www. ncbi.nlm.nih.gov/pubmed/22957819. DOI https://doi.org/ 10.1094/PHYTO-12-11-0342.

Jones, J.D. \& Dangl, J.L., (2006). The plant immune system. Nature, 444(7117): 323-329. Available from https://www. ncbi.nlm.nih.gov/pubmed/17108957. DOI https://doi.org/ 10.1038/nature05286.

Kelman, A., (1954). The relationship of pathogenicity in pseudomonas-solanacearum to colony appearance on a tetrazolium medium. Phytopathology, 44(12): 693-695. Available from < Go to ISI > ://WOS:A1954UP23800006.

Khan, M., Seto, D., Subramaniam, R. \& Desveaux, D., (2018). $\mathrm{Oh}$, the places they'll go! A survey of phytopathogen effectors and their host targets. Plant J, 93(4): 651-663. Available from https://www.ncbi.nlm.nih.gov/pubmed/ 29160935. DOI https://doi.org/10.1111/tpj.13780.

Landry, D., González-Fuente, M., Deslandes, L. \& Peeters, N., (2020). The large, diverse, and robust arsenal of ralstonia solanacearum type iii effectors and their in planta functions. Molecular Plant Pathology, 21(10): 1377-1388. Available from https://bsppjournals.onlinelibrary.wiley. com/doi/abs/10.1111/mpp.12977. DOI https://doi.org/10. 1111/mpp.12977.

Lavie, M., Shillington, E., Eguiluz, C., Grimsley, N. \& Boucher, C., (2002). Popp1, a new member of the yopj/ avrrxv family of type iii effector proteins, acts as a hostspecificity factor and modulates aggressiveness of ralstonia solanacearum. Mol Plant Microbe Interact, 15(10):
1058-1068. Available from https://www.ncbi.nlm.nih.gov/ pubmed/12437304. DOI https://doi.org/10.1094/MPMI. 2002.15.10.1058.

Lonjon, F., Turner, M., Henry, C., Rengel, D., Lohou, D., van de Kerkhove, Q., Cazale, A.C., Peeters, N., Genin, S. \& Vailleau, F., (2016). Comparative secretome analysis of ralstonia solanacearum type 3 secretion-associated mutants reveals a fine control of effector delivery, essential for bacterial pathogenicity. Mol Cell Proteomics, 15(2): 598-613. Available from https://www.ncbi.nlm.nih. gov/pubmed/26637540. DOI https://doi.org/10.1074/mcp. M115.051078.

Macho, A.P., (2016). Subversion of plant cellular functions by bacterial type-iii effectors: Beyond suppression of immunity. New Phytol, 210(1): 51-57. Available from https:// www.ncbi.nlm.nih.gov/pubmed/26306858. DOI https:// doi.org/10.1111/nph.13605.

Macho, A.P. \& Zipfel, C., (2015). Targeting of plant pattern recognition receptor-triggered immunity by bacterial typeiii secretion system effectors. Curr Opin Microbiol, 23: 14-22. Available from https://www.ncbi.nlm.nih.gov/pubmed/25461568. DOI https://doi.org/10.1016/j.mib.2014. 10.009 .

Mansfield, J., Genin, S., Magori, S., Citovsky, V., Sriariyanum, M., Ronald, P., Dow, M., Verdier, V., Beer, S.V., Machado, M.A., Toth, I., Salmond, G. \& Foster, G.D., (2012). Top 10 plant pathogenic bacteria in molecular plant pathology. Mol Plant Pathol, 13(6): 614-629. Available from https:// www.ncbi.nlm.nih.gov/pubmed/22672649. DOI https:// doi.org/10.1111/j.1364-3703.2012.00804.x.

Medina-Puche, L., Tan, H., Dogra, V., Wu, M., Rosas-Diaz, T., Wang, L., Ding, X., Zhang, D., Fu, X., Kim, C., \& Lozano-Duran, R. (2020). A defense pathway linking plasma membrane and chloroplasts and co-opted by pathogens. Cell, 182(5), 1109-1124.e1125. https://doi.org/10. 1016/j.cell.2020.07.020

Moon, H., Pandey, A., Yoon, H., Choi, S., Jeon, H., Prokchorchik, M., Jung, G., Witek, K., Valls, M., McCann, H.C., Kim, M.S., Jones, J.D.G., Segonzac, C. \& Sohn, K.H., (2021). Identification of ripaz1 as an avirulence determinant of ralstonia solanacearum in solanum americanum. Molecular Plant Pathology, 22(3): 317-333. Available from https://www.ncbi.nlm.nih.gov/pubmed/33389783. DOI https://doi.org/10.1111/mpp.13030.

Mukaihara, T. \& Tamura, N., (2009). Identification of novel ralstonia solanacearum type iii effector proteins through translocation analysis of hrpb-regulated gene products. Microbiology (Reading), 155(Pt 7): 2235-2244. Available from https://www.ncbi.nlm.nih.gov/pubmed/19406897. DOI https://doi.org/10.1099/mic.0.027763-0.

Nakano, M. \& Mukaihara, T., (2019a). Comprehensive identification of pti suppressors in type iii effector repertoire reveals that ralstonia solanacearum activates jasmonate signaling at two different steps. Int J Mol Sci, 20(23). Available from https://www.ncbi.nlm.nih.gov/pubmed/ 31795135. DOI https://doi.org/10.3390/ijms20235992.

Nakano, M. \& Mukaihara, T., (2019b). The type iii effector ripb from ralstonia solanacearum rs1000 acts as a major avirulence factor in nicotiana benthamiana and other nicotiana species. Mol Plant Pathol, 20(9): 1237-1251. 
Available from https://www.ncbi.nlm.nih.gov/pubmed/ 31218811. DOI https://doi.org/10.1111/mpp.12824.

Norman, D.J., Bocsanczy, A.M., Harmon, P., Harmon, C.L. \& Khan, A., (2017). Bacterial wilt outbreaks of multiple sequevars on blueberries in florida. Phytopathology, 107(12): 102-102. Available from < Go to ISI >:// WOS:000423236200529.

Norman, D.J., Bocsanczy, A.M., Harmon, P., Harmon, C.L. \& Khan, A., (2018). First report of bacterial wilt disease caused by ralstonia solanacearum on blueberries (vacciniunz corymbosum) in florida. Plant Disease, 102(2): 438-438. Available from <Go to ISI>:// WOS:000423496600025. DOI https://doi.org/10.1094/ Pdis-06-17-0889-Pdn.

Norman, D.J., Zapata, M., Gabriel, D.W., Duan, Y.P., Yuen, J.M., Mangravita-Novo, A. \& Donahoo, R.S., (2009). Genetic diversity and host range variation of ralstonia solanacearum strains entering north america. Phytopathology, 99(9): 1070-1077. Available from http://www. ncbi.nlm.nih.gov/entrez/query.fcgi?cmd=Retrieve $\& \mathrm{db}=$ PubMed\&dopt $=$ Citation\&list_uids $=19671009$. DOI https://doi.org/10.1094/PHYTO-99-9-1070.

Oh, C.S. \& Martin, G.B., (2011). Effector-triggered immunity mediated by the pto kinase. Trends Plant Sci, 16(3): 132-140. Available from https://www.ncbi.nlm.nih.gov/ pubmed/21112235. DOI https://doi.org/10.1016/j.tplants. 2010.11.001.

Oliveros, J.C., 2007-2015. Venny. An interactive tool for comparing lists with venn's diagrams. .

Opeña, R.T., (1990). Genetic improvement of selected vegetables for the tropics and sub-tropics. Tropical Agriculture Research Series (Japan).

Peeters, N., Carrere, S., Anisimova, M., Plener, L., Cazale, A.C. \& Genin, S., (2013). Repertoire, unified nomenclature and evolution of the type iii effector gene set in the ralstonia solanacearum species complex. BMC Genomics, 14: 859. Available from https://www.ncbi.nlm.nih. gov/pubmed/24314259. DOI https://doi.org/10.1186/ 1471-2164-14-859.

Poueymiro, M., Cunnac, S., Barberis, P., Deslandes, L., Peeters, N., Cazale-Noel, A.C., Boucher, C. \& Genin, S., (2009). Two type iii secretion system effectors from ralstonia solanacearum gmi1000 determine host-range specificity on tobacco. Mol Plant Microbe Interact, 22(5): 538-550. Available from https://www.ncbi.nlm. nih.gov/pubmed/19348572. DOI https://doi.org/10.1094/ MPMI-22-5-0538.

Prior, P., Ailloud, F., Dalsing, B.L., Remenant, B., Sanchez, B. \& Allen, C., (2016). Genomic and proteomic evidence supporting the division of the plant pathogen ralstonia solanacearum into three species. BMC Genomics, 17: 90. Available from https://www.ncbi.nlm.nih. gov/pubmed/26830494. DOI https://doi.org/10.1186/ s12864-016-2413-z.

Prior, P. \& Fegan, M., 2005. Recent developments in the phylogeny and classification of ralstonia solanacearum. In: First International Symposium on Tomato Diseases, $\mathrm{T}$. Momol \& J. B. Jones (Eds.). ISHS Acta Horticulturae: pp: $127-136$

Ramesh, R., Gaitonde, S., Achari, G., Asolkar, T., Singh, N.P., Carrere, S., Genin, S. \& Peeters, N., (2014). Genome sequencing of ralstonia solanacearum biovar 3, phylotype i, strains rs-09-161 and rs-10-244, isolated from eggplant and chili in india. Genome Announc, 2(3). Available from https://www.ncbi.nlm.nih.gov/pubmed/24874667. DOI https://doi.org/10.1128/genomeA.00323-14.

Remenant, B., Coupat-Goutaland, B., Guidot, A., Cellier, G., Wicker, E., Allen, C., Fegan, M., Pruvost, O., Elbaz, M., Calteau, A., Salvignol, G., Mornico, D., Mangenot, S., Barbe, V., Medigue, C. \& Prior, P., (2010). Genomes of three tomato pathogens within the ralstonia solanacearum species complex reveal significant evolutionary divergence. BMC Genomics, 11: 379. Available from https:// www.ncbi.nlm.nih.gov/pubmed/20550686. DOI https:// doi.org/10.1186/1471-2164-11-379.

Remenant, B., de Cambiaire, J.C., Cellier, G., Jacobs, J.M., Mangenot, S., Barbe, V., Lajus, A., Vallenet, D., Medigue, C., Fegan, M., Allen, C. \& Prior, P., (2011). Ralstonia syzygii, the blood disease bacterium and some asian r. Solanacearum strains form a single genomic species despite divergent lifestyles. PLoS One, 6(9): e24356. Available from https://www.ncbi.nlm.nih.gov/pubmed/ 21931687. DOI https://doi.org/10.1371/journal.pone. 0024356.

Remigi, P., Anisimova, M., Guidot, A., Genin, S. \& Peeters, N., (2011). Functional diversification of the gala type iii effector family contributes to ralstonia solanacearum adaptation on different plant hosts. New Phytol, 192(4): 976-987. Available from https://www.ncbi.nlm.nih.gov/ pubmed/21902695. DOI https://doi.org/10.1111/j.14698137.2011.03854.x.

Rodriguez-R, L.M. \& Konstantinidis, K.T., (2016). The enveomics collection: A toolbox for specialized analyses of microbial genomes and metagenomes. PeerJ Preprints(4:e1900v1). Available from https://doi.org/10. 7287/peerj.preprints.1900v1.

Rohmer, L., Guttman, D.S. \& Dangl, J.L., (2004). Diverse evolutionary mechanisms shape the type iii effector virulence factor repertoire in the plant pathogen pseudomonas syringae. Genetics, 167(3): 1341-1360. Available from https:// www.ncbi.nlm.nih.gov/pubmed/15280247. DOI https:// doi.org/10.1534/genetics.103.019638.

Ruhl, G., Twieg, E., DeVries, R., Levy, L., Byrne, J., Mollov, D. \& Taylor, N., (2011). First report of bacterial wilt in mandevilla (= dipladenia) splendens 'red riding hood' in the united states caused by ralstonia solanacearum biovar 3. Plant Dis, 95(5): 614. Available from https://www.ncbi. nlm.nih.gov/pubmed/30731978. DOI https://doi.org/10. 1094/PDIS-11-10-0858.

Sabbagh, C.R.R., Carrere, S., Lonjon, F., Vailleau, F., Macho, A.P., Genin, S. \& Peeters, N., (2019). Pangenomic type iii effector database of the plant pathogenic ralstonia spp. PeerJ, 7: e7346. Available from https://www.ncbi.nlm. nih.gov/pubmed/31579561. DOI https://doi.org/10.7717/ peerj.7346.

Safni, I., Cleenwerck, I., De Vos, P., Fegan, M., Sly, L. \& Kappler, U., (2014). Polyphasic taxonomic revision of the ralstonia solanacearum species complex: Proposal to emend the descriptions of ralstonia solanacearum and ralstonia syzygii and reclassify current r. Syzygii strains as ralstonia syzygii subsp. Syzygii subsp. Nov., r. Solanacearum phylotype iv strains as ralstonia syzygii subsp. Indonesiensis 
subsp. Nov., banana blood disease bacterium strains as ralstonia syzygii subsp. Celebesensis subsp. Nov. And r. Solanacearum phylotype i and iii strains as ralstonia pseudosolanacearum sp. Nov. Int J Syst Evol Microbiol, 64(Pt 9): 3087-3103. Available from https://www.ncbi.nlm. nih.gov/pubmed/24944341. https://doi.org/10.1099/ijs.0. 066712-0.

Sarkar, S.F., Gordon, J.S., Martin, G.B. \& Guttman, D.S., (2006). Comparative genomics of host-specific virulence in pseudomonas syringae. Genetics, 174(2): 1041-1056. Available from https://www.ncbi.nlm.nih.gov/pubmed/ 16951068. DOI https://doi.org/10.1534/genetics.106. 060996.

Schechter, L.M., Vencato, M., Jordan, K.L., Schneider, S.E., Schneider, D.J. \& Collmer, A., (2006). Multiple approaches to a complete inventory of pseudomonas syringae pv. Tomato dc3000 type iii secretion system effector proteins. Mol Plant Microbe Interact, 19(11): 1180-1192. Available from https://www.ncbi.nlm.nih. gov/pubmed/17073301. DOI https://doi.org/10.1094/ MPMI-19-1180.

Shao, F., Merritt, P.M., Bao, Z., Innes, R.W. \& Dixon, J.E., (2002). A yersinia effector and a pseudomonas avirulence protein define a family of cysteine proteases functioning in bacterial pathogenesis. Cell, 109(5): 575-588. Available from https://www.ncbi.nlm.nih.gov/pubmed/12062101. DOI https://doi.org/10.1016/s0092-8674(02)00766-3.

Tjou-Tam-Sin, N.N.A., van de Bilt, J.L.J., Westenberg, M., Gorkink-Smits, P., Landman, N.M. \& Bergsma-Vlami, M., (2017). Assessing the pathogenic ability of ralstonia pseudosolanacearum (ralstonia solanacearum phylotype i) from ornamental rosa spp. Plants. Front Plant Sci, 8: 1895. Available from https://www.ncbi.nlm.nih.gov/pubmed/29163615. DOI https://doi.org/10.3389/fpls.2017. 01895.

Tran, T.M., Jacobs, J.M., Huerta, A., Milling, A., Weibel, J. \& Allen, C., (2016). Sensitive, secure detection of race 3 biovar 2 and native u.S. Strains of ralstonia solanacearum.
Plant Dis, 100(3): 630-639. Available from https://www. ncbi.nlm.nih.gov/pubmed/30688589. DOI https://doi.org/ 10.1094/PDIS-12-14-1327-RE.

Walter, J.M., (1967). Hereditary resistance to disease in tomato. Annual Review of Phytopathology, 5: 131-\&. Available from < Go to ISI>://WOS:A1967A134500007. DOI https://doi.org/10.1146/annurev.py.05.090167.001023.

Wang, J.-F., Hanson, P. \& Barnes, J., (1998). Worldwide evaluation of an international set of resistance sources to bacterial wilt in tomato. In: Bacterial wilt disease. Springer: pp: 269-275.

Wang, K., Remigi, P., Anisimova, M., Lonjon, F., Kars, I., Kajava, A., Li, C.H., Cheng, C.P., Vailleau, F., Genin, S. \& Peeters, N., (2016). Functional assignment to positively selected sites in the core type iii effector ripg7 from ralstonia solanacearum. Molecular Plant Pathology, 17(4): 553564. Available from https://www.ncbi.nlm.nih.gov/pubmed/26300048. DOI https://doi.org/10.1111/mpp.12302.

Weibel, J., Tran, T.M., Bocsanczy, A.M., Daughtrey, M., Norman, D.J., Mejia, L. \& Allen, C., (2016). A ralstonia solanacearum strain from guatemala infects diverse flower crops, including new asymptomatic hosts vinca and sutera, and causes symptoms in geranium, mandevilla vine, and new host african daisy (osteospermum ecklonis). Plant Health Progress, 17(2): 114-121. Available from https:// apsjournals.apsnet.org/doi/abs/10.1094/PHP-RS-16-0001. DOI https://doi.org/10.1094/php-rs-16-0001.

Wicker, E., Lefeuvre, P., de Cambiaire, J.C., Lemaire, C., Poussier, S. \& Prior, P., (2012). Contrasting recombination patterns and demographic histories of the plant pathogen ralstonia solanacearum inferred from mlsa. ISME $J$, 6(5): 961-974. Available from https://www.ncbi.nlm.nih. gov/pubmed/22094345. DOI https://doi.org/10.1038/ ismej.2011.160.

Zipfel, C., (2014). Plant pattern-recognition receptors. Trends Immunol, 35(7): 345-351. Available from https://www. ncbi.nlm.nih.gov/pubmed/24946686. DOI https://doi.org/ 10.1016/j.it.2014.05.004. 